\title{
PENGARUH PROMOSI JABATAN DAN KOMPENSASI TERHADAP KEPUASAN KERJA KARYAWAN PADA PT. PERWITA MARGASAKTI JAKARTA
}

\section{THE INFLUENCE OF PROMOTION AND COMPENSATION TO THE REST OF JOB SATISFACTION EMPLOYE IN PT. PERWITA MARGASAKTI JAKARTA}

\author{
Silviana Damayanti ${ }^{1}$; Sri Harini ${ }^{2)}$ \\ Program Studi Manajemen, Fakultas Ekonomi, Universitas Djuanda Bogor \\ Email : silviana.damayanti@unida.ac.id
}

\begin{abstract}
Human Resource (HR) is a very important asset, especialy for an organization or company. The importance of the role of Human Resource in a company, organization or company should pay attention to the aspects of work related to Human Resources. In improving employe statisfaction can be done in various ways. For excample, through provision of adequate compensation and promotion. The purpose of this study is to determine the effect of promotion and compensation on employe job satisfaction at PT. Perwita Margasakti. The method used is multiple linear regressionb analysis. The population used is all employees of company which amounted to 79 employees. The result of the rese(ach shows promotion and compensation simultaneusly positive and significant effect on job satisfaction. Partially promotion have a positive and significant impact on job satisfaction, and compensation also have a positive and significant effect on job satisfaction.
\end{abstract}

Keywords : Promotion, Compensation, Job Satisfaction.

\begin{abstract}
ABSTRAK
Sumber Daya Manusia (SDM) ialah aset yang sangat penting, terutama bagi organisasi maupun perusahaan. Mengingat besarnya peran dari Sumber Daya Manusia (SDM) dalam suatu organisasi maupun perusahaan, sudah sepantasnya apabila suatu organisasi atau perusahaan memperhatikan semua aspek-aspek mengenai Sumber Daya Manusia (SDM). Dalam meningkatkan kepuasan kerja berbagai cara dapat dilakukan misalnya, dengan pemberian kompensasi dan promosi jabatan. Tujuan penelitian ini yaitu untuk mengetahui pengaruh promosi jabatan dan kompensasi terhadap kepuasan kerja karyawan pada PT. Perwita Margasakti. Metode yang digunakan adalah analisis regresi linier berganda. Populasi yang digunakan adalah karyawan perusahaan yang secara keseluruhan berjumlah 79 orang karyawan. Hasil penelitian menunjukkan promosi jabatan dan kompensasi secara simultan berpengaruh positif dan signifikan terhadap kepuasan kerja. Secara parsial promosi jabatan berpengaruh positif dan signifikan terhadap kepuasan kerja, dan kompensasi juga berpengaruh secara positif dan signifikan terhadap kepuasan kerja.
\end{abstract}

Kata Kunci : Promosi Jabatan, Kompensasi, Kepuasan Kerja Karyawan 


\section{PENDAHULUAN}

Dewasa ini, persaingan antarperusahaan semakin ketat dalam berbagai industri di Indonesia. Setiap organisasi maupun perusahaan sangat berharap para karyawannya mampu bekerja optimal dengan mengerahkan seluruh daya dan upaya dalam mewujudkan cita-cita perusahaan. Setiap karyawan di sebuah perusahaan mempunyai pemikiran dan keinginan yang berbeda-beda. Karyawan adalah aset yang paling berharga bagi perusahaan sehingga sudah sepatutnya dipertahankan dan diberikan penghargaan baik sebagai individu maupun makhluk sosial. Hal ini menjadi tugas manajemen untuk menyatukan pemikiran seluruh karyawan agar tercipta kepuasan kerja bagi semua karyawan di perusahaan.

SDM merupakan bagian terpenting suatu perusahaan di bidang jasa maupun non jasa. Semua SDM yang turut aktif dengan peran dan tugasnya, yaitu mendukung kemajuan perusahaan untuk meraih tujuan.

Menurut Hasibuan (2012), kepuasan kerja diartikan sebagai sebuah sikap emosional menyukai pekerjaanya. Kepuasan kerja penting untuk dipenuhi oleh perusahaan keinginan karyawan dapat terwujud serta tujuan perusahaan tercapai. Lebih lanjut lagi, dikemukan pula oleh Mangkunegara (2009) bahwa instrumen kepuasan kerja meliputi gaji, kompensasi, promosi, supervisi, rekan serta situasi kerja yang sangat diingikan karyawan. Upaya yang dilakukan oleh suatu perusahaan dalam memberi kepuasan kerja dengan memberikan gaji dan promosi jabatan.

Rivai (2008) bahwa kompensasi adalah imbalan yang diperoleh karyawan karena telah mengoptimalkan semua kemampuan yang dimiliki dan kecerdasannya yang diberikan untuk perusahaan. Adapun faktor yang diperhatikan dalam pemberian kompensasi, menurut Mangkunegara (2009), faktor-faktor kompensasi yaitu faktor pemerintah, kerjasama, standar biaya hidup karyawan, ukuran upah yang lama dengan upah yang baru dibandingkan, permintaan dan persediaan, serta kemampuan perusahaan membayar. Sebaliknya, Hasibuan (2012) menjelaskan bahwa promosi jabatan ialah perubahan posisi pekerjaan di mana posisi pekerjaan naik menjadi lebih tinggi sehingga tanggungjawab pekerjaan bertambah seiring penghasilan juga meningkat. Dalam ketentuan pemberian promosi jabatan ada faktor-faktor yang harus dikaji ulang oleh perusahaan, yaitu pengalaman, kecakapan dan gabungan antara pekerjaan sebelumnya dan keahliannya.

Keberhasilan sebuah perusahaan dalam memenuhin kepuasan kerja kepada karyawan berdampak terhadap keberlangsungan sebuah perusahaan. Adapun dampak positif yang bisa ditimbulkan antara lain, yaitu prestasi kerja karyawan semakin meningkat, pencapaian visi perusahaan, tingkat kedisipinan karyawan, terjadi hubungan kerja dengan perusahaan, serta kondisi keluar masuknya karyawan atau LTO (Labour Turn Over) yang stabil. Sebaliknya, dampak negatif akibat kepuasan kerja rendah antara lain, yaitu akan berpengaruh pada turnover karyawan, besarnya biaya untuk perekrutan karyawan, biaya pelatihan, serta hal-hal lain.

Dari hasil pengamatan selama penelitian disebutkan bahwa pencapaian kepuasan kerja terbilang masih rendah. Lebih lanjut lagi, untuk mengetahui besarnya kondisi LTO (Labour Turn Over) pada PT. Perwita Margaskti, maka berikut ini adalah Tabel 1 yang menunjukkan data kondisi LTO (Labour Turn Over) selama 4 (empat) tahun terakhir dari tahun 2013 sampai dengan tahun 2016 yang mengalami fluktuasi. 
Tabel 1

Jumlah Karyawan Masuk dan karyawan Keluar PT. Perwita Margasakti Tahun 2013-2016

\begin{tabular}{llllll}
\hline Tahun & $\begin{array}{l}\text { Awal } \\
\text { Tahun } \\
(2)\end{array}$ & $\begin{array}{l}\text { Karyawan } \\
\text { Masuk } \\
(3)\end{array}$ & $\begin{array}{l}\text { Karyawan } \\
\text { Keluar } \\
(4)\end{array}$ & $\begin{array}{l}\text { Akhir } \\
\text { Tahun } \\
(5)\end{array}$ & $\begin{array}{l}\text { LTO }(\%) \\
(6)=: \frac{(4)-(3)}{\frac{1}{2}(2)+(5)} \times 100 \\
\%\end{array}$ \\
\hline 2013 & 80 & 5 & 7 & 78 & 6,32 \\
2014 & 78 & 8 & 8 & 78 & 0 \\
2015 & 78 & 12 & 10 & 80 & $-6,32$ \\
2016 & 80 & 10 & 11 & 79 & 3,34 \\
\hline Rata-rata & 80 & 8,8 & 9 & 79 & 3,2 \\
\hline
\end{tabular}

Sumber: PT. Perwita Margasakti, Jakarta

Pada Tabel 1. terlihat bahwa kondisi LTO (Labour Turn Over) berfluktuatif dari 2013 sampai tahun 2016. Berdasarkan Tabel 1.1, LTO (Labour Turn Over) tertinggi terjadi di tahun 2013 yaitu sebesar 6,32\%. Artinya bahwa perputaran karyawan yang keluar dan masuk pada tahun 2013 yaitu sebesar 6,32\% dari jumlah karyawan awal tahun dan akhir tahun. Adapun nilai rata-ratanya sebesar 3,2\% setiap tahunnya. Artinya bahwa tingkat LTO (Labour Turn Over) belum sesuai standar perusahaan, karena PT. Perwita Margaskti menetapkan standar maksimal tingkat LTO (Labour Turn Over) sebesar 2\%. Tingkat turnover yang tinggi, diduga karena rendahnya kepuasan kerja karyawannya.

Beberapa upaya PT. Perwita Margaskti agar kepuasaan kerja karyawan meningkat, yaitu dengan memberikan reward berupa adanya pomosi jabatan dan pemberian kompensasi. Akan tetapi, pelaksanaan dalam hal pemberian reward berupa promosi jabatan tersebut masih dirasa belum adil dan merata, karena kurangnya rasa percaya perusahaan terhadap karyawan.

\section{METODE}

Hasibuan (2012) menjelasksan bahwa MSDM artinya ilmu yang memiliki seni untuk mengatur hubungan serta peran tenaga kerja supaya optimal agar tujuan perusahaan terwujud, karyawan dan masyarakat. Promosi jabatan menurut Hasibuan (2012) ialah perpindahan yang memperbesar wewenang dan amanah karyawan ke level jabatan berikutnya didalam suatu organisasi sehingga kompensasi yang dihasilkan akan jauh lebih besar. Adapun pengertian kompensasi menurut Simamora (2005) adalah pemberian dalam bentuk uang dan jasa sekaligus tunjangan yang diterima oleh para karyawan sebagai hubungan kepegawaian. Mangkunegara (2009) mengemukakan bahwa kepuasan kerja diartikan sebagai suatu penyokong atau tidak menyokongnya yang dirasakan karyawan selama bekerja di perusahaan tersebut.

Bentuk penelitiannya adalah bentuk deskriptif dan bentuk verifikatif. Jenis datanya adalah primer berupa himpunan informasi dengan metode wawancara dan menggunakan kuesioner terstruktur terhadap 79 karyawan PT. Perwita Margaskti.

Bertolak dari seluruh uraian landasan teori di atas, maka dirumuskan paradigma pengaruh promosi jabatan dan kompensasi terhadap kepuasan kerja karyawan PT. Perwita Margaskti. Secara garis besar dapat digambarkan melalui sebuah bagan alur kerangka pikiran pada Gambar 1. 
Pengaruh Promosi Jabatan dan Kompensasi terhadap Kepuasan Kerja Karyawan pada PT. Parwita Margasakti Jakarta

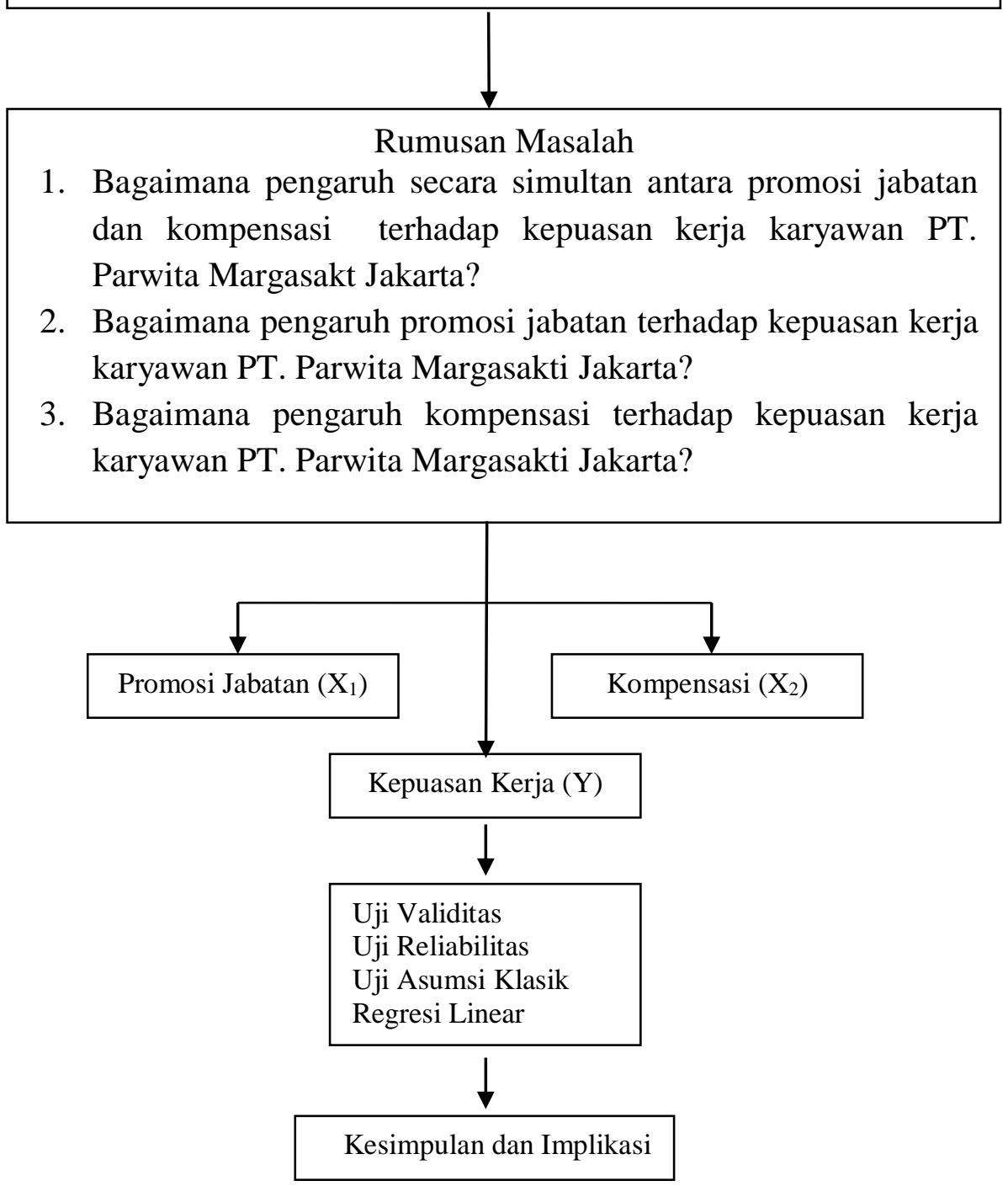

Gambar 1. Bagan Alur Kerangka Pikiran

\section{Hipotesis Penelitian}

$\mathrm{H}_{1} \quad$ : Promosi jabatan dan kompensasi secara simultan berpengaruh positif dan signifikan terhadap kepuasan kerja karyawan.

$\mathrm{H}_{2}$ : Promosi jabatan berpengaruh positif dan signifikan terhadap kepuasan kerja karyawan.

$\mathrm{H}_{3}$ : Kompensasi berpengaruh positif dan signifikan terhadap kepuasan kerja karyawan. 


\section{Operasional Variabel}

Untuk menjawab permasalahan, variabel yang dianalisis yang terdiri dari variabel dependent promosi jabatan $\left(\mathrm{X}_{1}\right)$, kompensasi $\left(\mathrm{X}_{2}\right)$ dan variabel independent yaitu kepuasan kerja karyawan (Y). Adapun skala pengukurannya adalah skala ordinal. Berikut ini adalah operasional variabel penelitian. seluruhnya. Oleh karenanya, penelitian ini disebut sebagai penelitian population. Adapun teknik penentuan sampel yang dianggap representatif adalah dengan mengambil semua jumlah karyawan pada PT. Perwita Margaskti sebanyak 79 orang. Artinya, keseluruhan karyawan yang berjumlah 79 orang sebagai polulasi juga sebagai sampelnya. Sedangkan, cara pengumpulan data, yaitu: 1) Studi kepustakaan di mana penulis meneliti dan

\section{Tabel 2 Operasionalisasi Variabel}

\begin{tabular}{|c|c|c|c|c|}
\hline Variabel & Definisi & Indikator & Skala Ukur & Item Pertanyaan \\
\hline Promosi Jabatan $\left(\mathrm{X}_{1}\right)$ & $\begin{array}{l}\text { Hasibuan (2012), } \\
\text { promosi jabatan adalah } \\
\text { pepindahan yang mem } \\
\text { perbesar wewenang dan } \\
\text { tanggung jawab } \\
\text { karyawan ke jabatan } \\
\text { yang lebih tinggi di } \\
\text { dalam suatu organisasi } \\
\text { sehingga kewajban, hak, } \\
\text { status dan penghsilannya } \\
\text { semakin besar. . }\end{array}$ & $\begin{array}{ll}\text { 1. } & \text { Kejujuran } \\
\text { 2. } & \text { Disiplin } \\
\text { 3. } & \text { Kerjasama } \\
\text { 4. } & \text { Prestasi Kerja } \\
\text { 5. } & \text { Kecakapan } \\
\text { 6. } & \text { Komunikatif } \\
\text { 7. } & \text { Loyalitas } \\
\text { 8. } & \text { Kepemimpinan } \\
\text { 9. } & \text { Pendidikan }\end{array}$ & Ordinal & $\begin{array}{l}1-2 \\
3-4 \\
5-6 \\
7-8 \\
9-10 \\
11-12 \\
13-14 \\
15-16 \\
17-18\end{array}$ \\
\hline Kompensasi $\left(\mathrm{X}_{2}\right)$ & $\begin{array}{l}\text { Menurut Simamora } \\
(2005 \text { ) adalah imbalan } \\
\text { finansial dan jasa } \\
\text { nirwujud dan tunjangan } \\
\text { yang diterima oleh para } \\
\text { karyawan sebaggai } \\
\text { bagian dari hubungan } \\
\text { kepegawaian. }\end{array}$ & $\begin{array}{l}\text { 1. Upah dan Gaji } \\
\text { 2. Insentif } \\
\text { 3. Tunjangan } \\
\text { 4. Fasilitas }\end{array}$ & Ordinal & $\begin{array}{l}1-2 \\
3-4 \\
5-6 \\
7-8\end{array}$ \\
\hline Kepuasan kerja (Y) & $\begin{array}{l}\text { Mangkunegara (2009), } \\
\text { kepuasan kerja adalah } \\
\text { perasaan penyokong atau } \\
\text { tidak menyokng yang } \\
\text { dialami karyawan dalam } \\
\text { bekerja. }\end{array}$ & $\begin{array}{l}\text { 1. Turnover } \\
\text { 2. Tingkat } \\
\text { ketidakhadiran } \\
\text { kerja } \\
\text { 3. Umur } \\
\text { 4. Tingkat } \\
\text { pekerjaan }\end{array}$ & Ordinal & $\begin{array}{l}1-2 \\
3-4 \\
5-6 \\
7-8\end{array}$ \\
\hline
\end{tabular}

\section{Sampel Penelitian}

Arikunto (2006) menjelaskan bahwa ukuran suatu sampel berdasarkan dengan suatu populasi atau jumlah responden agar dapat menjadi sampel penelitian apabila populasi $<100$ (kurang dari seratus) sebaiknya diambil mengkaji lebih dalam lagi kebenaran teori yang sesuai melalui buku, jurnal, skripsi penelitian terdahulu, dan publikasi lainnya; 2) Studi lapangan terdiri dari wawancara, observation, dan kuesioner. 


\section{Pengujian Instrumen}

Uji validitas dilakukan untuk mengetahui tingkat kevalidan dari kuesioner yang dipergunakan dalam pengumpulan data, jika dari hasil tersebut diperoleh $r_{\text {hitung }}>r_{\text {tabel }}(0,3)$ maka data tersebut adalah valid berarti layak untuk digunakan dalam pengujian hipotesis, sedangkan jika $r_{\text {hitung }}<r_{\text {tabel }}(0,3)$ menunjukan bahwa data tersebut tidak valid berarti tidak layak untuk digunakan didalam pengujan hipotesis.

Berdasarkan uji validitas pada pernyataan variabel dari variabel $\mathrm{X}$ serta komitmen variabel $\mathrm{Y}$ menggambarkan instrument disebut valid karena nilai korelasi sesuai dengan nilai yang dipakai yaitu rhitung $\geq$ rtabel yang dijelaskan bahwa nilai-nilai itu lebih besar sama dengan yaitu $(\geq 0,3)$.

Sedangkan untuk mengukur koefisien keandalan (reability) kuesioner dengan cara menggunakan Cronbach Alpha diuji pada alpha 0 (nol) - 1 (satu). Kriteria pengujiannya adalah jika $r$ hitung $\geq r_{\text {tabel }}$ yang berarti reliabel, serta sebaliknya jika $r_{\text {hitung }}<r_{\text {tabel }}$ yang artinya tidak reliabel. Suatu instrument dapat dinyatakan reliabel bila memiliki nilai alpha 0,6 atau lebih. Dengan hasil bahwa variabel penelitian ini memenuhi uji reliabilitas dimana alpha $\geq 0,6$. Dengan demikian, maka semua variabel penelitian dinyatakan reliable karena didapatkan hasil $r_{\text {hitung }} \geq r_{\text {tabel }}$.

\section{Uji Asumsi Klasik}

\section{Uji Normalitas}

Berdasarkan uji ini memakai grafik P-Plot dimana gambar P-Plot yang dapat diartikan bahwa data terdistribusi normal sebab data menyebar dan mengkuti arah garis diagonal, jadi model regresi memenuhi normalitas dan model regresi telah memenuhi uji asumsi normalitas. Sedangkan untuk mendukung dan membuktikan hasil uji normalitas grafik perlu dilakukan Kolmogorov-Smirnov, output yang diketahui nilai dari signifikasi (Asymp.Sig 2-tailed) sebesar 0,588.
Karena signifikasi >0,05 $(0,588>0,05)$, artinya data yang telah diuji terdistribusi normal.

\section{Uji Multikolinearitas}

Batasan yang dipakai ialah nilai tolerance $>0,05$ atau VIF $<5$. Model regresi linier berganda baik. Artinya, terbebas dari multikolinearitas sehingga dapat dipakai pada penelitian. Berdasarkan hasil dari uji multikolienaritas yang telah dianalisis nilai tolerance variabel independent $\left(\mathrm{X}_{1}\right) \quad 0,471$ dan $\left(\mathrm{X}_{2}\right)$ 0,471 yang berarti $(>0,05)$. Sementara untuk hasil dari nilai $\operatorname{VIF}\left(\mathrm{X}_{1}\right)$ 2,125 dan $\left(X_{2}\right)$ 2,125 yang menyatakan bahwa seluruh variabel independent $<5$, sehingga regresi penelitian tidak terjadi masalah dalam uji ini.

\section{Uji Heterokedastisitas}

Pengujian ini bermaksud untuk mengetahui kesamaan atau perbedaan varian suatu residual antar pengamatan.

Berdasarkan hasil pengujian heteroskedastisitas mengartikan tidak ada heteroskedastisitas pada persamaan regresi, sehingga dinyatakan layak untuk digunakan dalam memprediksi kepuasan kerja karyawan karena titik-titik pada sumbu Y dengan menyebar di atas dan di bawah angka 0 tanpa membentuk suatu pola.

\section{Metode Analisis dan Langkah-Langkahnya}

Melalui skala Likert variabel dapat diukur dan dijabarkan dengan memperhatikan tanggapan responden. Deskripsi tersebut digunakan untuk menghitung scoring dan nilai rata-rata.

Tabel 3 Skala Pengukuran Variabel

\begin{tabular}{ll}
\hline Alternatif Jawaban & Skor \\
\hline Sangat Setuju & 5 \\
Setuju & 4 \\
Netral & 3 \\
Tidak Setuju & 2 \\
Sangat Tidak Setuju & 1 \\
\hline Sumber: Sugiyono, 2009
\end{tabular}


Untuk mengukur pengaruh antara suatu variabel dependent dengan dua atau lebih variabel independent persamaan atau fungsi dalam regresi sebagai berikut:

$$
\boldsymbol{Y}=\boldsymbol{a}+\boldsymbol{\beta}_{1} \boldsymbol{X}_{1}+\boldsymbol{\beta}_{2} \boldsymbol{X}_{2}+\boldsymbol{e}
$$

Analisis korelasi berganda menurut Sugiyono (2009), menjelaskan kuatnya hubungan dari dua variabel atau lebih variabel dependent secara bersama-sama terhadap 1 (satu) variabel dependent. Berikut ini adalah pedoman penafsiran dari korelasi.

\section{Tabel 4 Interpretasi Nilai $r$}

\begin{tabular}{ll}
\hline Interval Nilai r & Interpretasi \\
\hline $0,001-0,200$ & Sangat Lemah \\
$0,201-0,400$ & Lemah \\
$0,401-0,600$ & Cukup Kuat \\
$0,601-0,800$ & Kuat \\
$0,801-1,000$ & Sangat Kuat \\
\hline
\end{tabular}

Sumber: Sugiyono, 2009

Menurut Ghozali (2011), koefisien determinasi digunakan untuk mengukur regresi dalam menerangkan variasi variabel dependent yang dengan menggunakan:

$$
\mathrm{KD}=\mathrm{r}^{2} \times 100 \%
$$

Uji F dilkukan untuk mengtahui pengaruh variabel independent secaraa simultan tehadap variabel dependent. (Ghozali, 2005), dan untuk menguji signifikan hubungan variabel dependent dengan variabel independent secara simultan. (Sugiyono, 2009). Dengan rumus Uji F sebagai berikut:

$$
F=\frac{R^{2} / K}{\left(1-R^{2}\right) /(n-K-1)}
$$

Uji $t$ digunakan untuk menguji pengaruh secara parsial variabel dependent dengan variabel terikat dengan asumsi tingkat signifikan $(\alpha)$ sebesar 0,05. Dengan tahap perumusan hipotesis, menentukan tingkat signifikansi ( $\alpha$ ), (dk) derajat kebebasan dengan rumus n-k-1. Menurut Sugiyono (2009), adapun rumus pada Uji t yaitu:

$$
t=\frac{r(n-2)}{\left(1-r^{2}\right)}
$$

Hasil dari pengujian hipotesis tersebut adalah:

a) Bila $t$ hitung lebih kecil dari atau sama dengan $\mathrm{t}_{\text {tabel }}$ ( $\mathrm{t}_{\text {hitung }} \leq \mathrm{t}_{\text {tabel }}$ ) pada $\alpha=0,05$ maka Ho di terima dan Ha ditolak.

b) Bila $t_{\text {hitung lebih besar dari } t_{\text {tabel }}\left(t_{\text {hitung }}>t_{\text {tabel }}\right)}$ pada $\alpha=0,05$ maka Ho ditolak dan Ha di terima.

\section{HASIL DAN PEMBAHASAN}

PT. Perwita Margasakti Jakarta adalah perusahaan yang melakukan usaha di bisnis property khususnya mengelola gedung Mal Ambasador. Perusahaan ini merupakan salah satu perusahaan yang bernaung dibawah kepemimpinan Sinar Mas Land yang berlokasi di Gedung Mal Ambasador Lt. 4, Jl. Prof. Dr. Satrio, Jakarta Selatan.

\section{Deskripsi Responden}

Objek yang diteliti adalah karyawan PT.Perwita Margasakti Jakarta. Adapun karakteristik karyawan dapat dijelaskan berdasarkan dari jenis kelamin, usia, masa kerja dan pendidikan terakhir. Kuesioner disebar kepada 79 karyawan sebagai berikut:

Tabel 5 Rekapitulasi Karakteristik Karyawan

\begin{tabular}{|l|l|l|}
\hline Kriteria & Prosentase & Keterangan \\
\hline Jenis Kelamin & $57 \%$ & Laki-laki \\
\hline Usia & $70 \%$ & $20 \mathrm{~s} / \mathrm{d} 28$ tahun \\
\hline Masa Kerja & $87 \%$ & $1 \mathrm{~s} / \mathrm{d} 10$ tahun \\
\hline Pendidikan Terakhir & $56 \%$ & SMA/Sederajat \\
\hline
\end{tabular}


Berdasarkan Tabel 5 disimpulkan bahwa karyawan sebanyak $57 \%$ adalah laki-laki, dengan usia 20 s/d 28 tahun sebanyak $70 \%$, dengan masa kerja 1 s/d 10 tahun sebanyak $87 \%$, dan pendidikan terakhir SMA/Sederajat sebanyak 56\%. Adapun tanggapan karyawan mengenai indikator promosi jabatan adalah: dalam perusahaan tersebut. Sedangkan untuk memperoleh promosi jabatan karyawan harus mencapai persyaratan dan prosedur dari perusahaan. Hal inilah yang akhirnya membuat karyawan termotivasi terus-menerus berusaha meningkatkan prestasi kerjanya.

\section{Tabel 6. Tanggapan Karyawan Mengenai Promosi Jabatan}

\begin{tabular}{|c|c|c|c|}
\hline No & Uraian & $\begin{array}{l}\text { Penilaian } \\
\text { Resp. }\end{array}$ & Keterangan \\
\hline 1 & Kejujuran dalam bekerja & 3,34 & Kejujuran dalam bekerja cukup baik untuk memenuhi syarat promosi jabatan \\
\hline 2 & $\begin{array}{ll}\begin{array}{l}\text { Kejujuran } \\
\text { melaksanakan tugas }\end{array} & \text { dalam } \\
\end{array}$ & 3,10 & $\begin{array}{l}\text { Kejujuran dalam melaksanakan tugas cukup baik untuk memenuhi syarat } \\
\text { pemberian promosi jabatan }\end{array}$ \\
\hline 3 & Kedisiplinan dalam bekerja & 3,11 & $\begin{array}{l}\text { Kedisiplinan dalam bekerja cukup baik untuk memenuhi syarat promosi } \\
\text { jabatan. }\end{array}$ \\
\hline 4 & $\begin{array}{lll}\begin{array}{l}\text { Mentaati } \\
\text { peraturan }\end{array} & \text { prosedur dan } \\
\end{array}$ & 3,55 & $\begin{array}{l}\text { Karyawan mentaati prosedur dan peraturan dengan baik untuk mendapat } \\
\text { promosi jabatan }\end{array}$ \\
\hline 5 & $\begin{array}{l}\text { Menyelesaikan pekerjaan } \\
\text { bersama tim }\end{array}$ & 3,02 & $\begin{array}{l}\text { Karyawan cukup baik untuk menyelesaikan pekerjaan bersama tim agar } \\
\text { pekerjaan dapat terselesaikan dengan cepat. }\end{array}$ \\
\hline 6 & $\begin{array}{lll}\begin{array}{l}\text { Bekerja } \\
\text { description }\end{array} & \text { sesuai } & \text { job } \\
\end{array}$ & 3,81 & $\begin{array}{l}\text { Karyawan bekerja sesuai job description dengan baik untuk mendukung } \\
\text { pemberian promosi jabatan. }\end{array}$ \\
\hline 7 & Pencapaian prestasi kerja & 3,09 & $\begin{array}{l}\text { Pencapaian prestasi kerja cukup baik untuk memenuhi syarat pemberian } \\
\text { promosi jabatan }\end{array}$ \\
\hline 8 & Penilaian prestasi kerja & 3,10 & Penilaian prestasi kerja cukup baik untuk memenuhi syarat promosi jabatan. \\
\hline 9 & $\begin{array}{l}\text { Berinovasi dalam tugas dan } \\
\text { pekerjaan }\end{array}$ & 3,13 & $\begin{array}{l}\text { Berinovasi dalam tugas dan pekerjaan cukup baik untuk memenuhi syarat } \\
\text { promosi jabatan. }\end{array}$ \\
\hline 10 & $\begin{array}{l}\text { Penyelesaian kerja secara } \\
\text { cepat dan rapih }\end{array}$ & 3,08 & lyelesaikan kerja secara cepat dan rapih dengan cukup baik. \\
\hline 11 & uan berkomunikasi & 3,14 & $\begin{array}{l}\text { Kemampuan berkomunikasi karyawan cukup baik untuk memenuhi syarat } \\
\text { promosi jabatan. }\end{array}$ \\
\hline 12 & $\begin{array}{l}\text { Kemampuan menerima dan } \\
\text { memberikan informasi }\end{array}$ & 3,66 & $\begin{array}{l}\text { Karyawan menerima dan memberikan informasi dengan baik, sehingga } \\
\text { memenuhi syarat untuk mendaptkan promosi jabatan. }\end{array}$ \\
\hline 13 & $\begin{array}{l}\text { Loyalitas } \\
\text { perusahaan }\end{array}$ & 3,25 & $\begin{array}{l}\text { Loyalitas terhadap perusahaan cukup baik untuk memenuhi syarat promosi } \\
\text { jabatan. }\end{array}$ \\
\hline 14 & $\begin{array}{l}\text { Berpartisipasi aktif di } \\
\text { kegiatan perusahaan }\end{array}$ & 3,10 & $\begin{array}{l}\text { Karyawan berpartisipasi aktif dikegiatan perusahaan dengan cukup baik, } \\
\text { untuk memenuhi syarat promosi jabatan. }\end{array}$ \\
\hline 15 & Pemimpin membina bawahan & 3,10 & $\begin{array}{l}\text { Pemimpin dengan cukup baik membina bawahan untuk mendapatkan } \\
\text { promosi jabatan. }\end{array}$ \\
\hline 16 & $\begin{array}{l}\text { Pemimpin mampu } \\
\text { memotivasi karyawan }\end{array}$ & 3,27 & $\begin{array}{l}\text { Pemimpin cukup baik memotivasi karyawan untuk mendapat kesempatan } \\
\text { promosi jabatan. }\end{array}$ \\
\hline 17 & $\begin{array}{l}\text { Penempatan kerja sesuai } \\
\text { pendidikan }\end{array}$ & 3,09 & $\begin{array}{l}\text { Penempatan kerja sesuai pendidikan dilakukan dengan cukup baik karena } \\
\text { sesuai dengan stndar pendidikan karyawan. }\end{array}$ \\
\hline 18 & $\begin{array}{l}\text { Pendidikan berpengaruh pada } \\
\text { promosi jabatan }\end{array}$ & 3,24 & $\begin{array}{l}\text { Karyawan menerima dengan cukup baik bahwa pendidikan berpengaruh } \\
\text { pada promosi jabatan sebagai dasar pemberian promosi jabatan. }\end{array}$ \\
\hline \multicolumn{2}{|r|}{ Rata-rata } & 3,23 & Cukup Baik \\
\hline
\end{tabular}

Berdasarkan Tabel 6 dari hasil rekapan tentang promosi jabatan diartikan bahwa ratarata nilainya cukup baik. Dengan demikian, dapat diartikan bahwa karyawan memahami dengan cukup baik penilaian-penilaian di
Adapun rekapitulasi tanggapan karyawan terhadap variabel kompensasi pada Tabel 7 di bawah ini. 
Tabel 7 Rekapitulasi Tanggapan Karyawan Mengenai Kompensasi

\begin{tabular}{|c|c|c|c|}
\hline No & Uraian & $\begin{array}{c}\text { Penilaian } \\
\text { Responden }\end{array}$ & Keterangan \\
\hline 1 & Standar gaji yang sesuai & 3,09 & $\begin{array}{l}\text { Standar gaji yang diterima karyawan cukup tinggi karena } \\
\text { sesuai UMR. }\end{array}$ \\
\hline 2 & Gaji sesuai beban kerja & 3,14 & $\begin{array}{l}\text { Gaji yang diterima karyawan cukup tinggi dan sudah } \\
\text { cukup sesuai dengan beban kerja. }\end{array}$ \\
\hline 3 & $\begin{array}{l}\text { Upah lembur yang diberikan } \\
\text { sesuai waktu kerja lembur }\end{array}$ & 3,56 & $\begin{array}{l}\text { Upah lembur yang diterima karyawan tinggi karena sesuai } \\
\text { dengan waktu lembur yang sudah digunakan. }\end{array}$ \\
\hline 4 & $\begin{array}{l}\text { Pemberian insentif } \text { sesuai } \\
\text { jabatan }\end{array}$ & 3,55 & $\begin{array}{l}\text { Pemberian insentif sesuai jabatan dilakukan dengan baik } \\
\text { karena karyawan menerima insentif sesuai peraturan } \\
\text { perusahaan. }\end{array}$ \\
\hline 5 & Tunjangan sesuai harapan & 3,28 & $\begin{array}{l}\text { Tunjangan yang diterima karyawan cukup tinggi dan } \\
\text { sesuai dengan harapan. }\end{array}$ \\
\hline 6 & $\begin{array}{l}\text { Pemenuhan kebutuhan baik } \\
\text { fisik maupun psikis }\end{array}$ & 3,30 & Pemenuhan kebutuhan secara fisik dan psikis cukup baik. \\
\hline 7 & $\begin{array}{l}\text { Fasilitas sesuai kebutuhan } \\
\text { kerja }\end{array}$ & 3,10 & $\begin{array}{l}\text { Fasilitas sesuai kebutuhan kerja yang disediakan sudah } \\
\text { cukup baik sehingga membantu pekerjaan karyawan. }\end{array}$ \\
\hline 8 & $\begin{array}{l}\text { Fasilitas } \quad \text { membantu } \\
\text { menyelesaikan pekerjaan }\end{array}$ & 3,87 & $\begin{array}{l}\text { Fasilitas untuk membantu menyelesaikan pekerjaan sudah } \\
\text { baik karena fasilitas yang ada sangat membantu karyawan } \\
\text { menyelesaikan pekerjaan }\end{array}$ \\
\hline & Rata-rata & $\mathbf{3 , 2 5}$ & Cukup Tinggi \\
\hline
\end{tabular}

Dari hasil rekapitulasi pada Tabel 7 diartikan bahwa rata-rata nilai kompensasi cukup tinggi, artinya karyawan yang menerima kompensasi sudah dianggap sudah sesuai.
Adapun rekapitulasi tanggapan karyawan terhadap kepuasan kerja pada Tabel 8 berikut:

Tabel 8. Rekapitulasi Tanggapan Kepuasan Kerja Karyawan

\begin{tabular}{|c|c|c|c|}
\hline No & Uraian & $\begin{array}{l}\text { Penilaian } \\
\text { Resp. }\end{array}$ & Keterangan \\
\hline 1 & Berganti pekerjaan & 3,10 & Karyawan cukup puas dengan pekerjaan saat ini \\
\hline 2 & Peluang kerja & 3,11 & Karyawan cukup puas dengan peluang kerja yang tersedia \\
\hline 3 & Sangsi tegas & 3,40 & $\begin{array}{l}\text { Karyawan sudah puas dengan sanksi tegas yang diterapkan } \\
\text { oleh perusahaan }\end{array}$ \\
\hline 4 & Kehadiran di hari kerja & 3,40 & $\begin{array}{l}\text { Karyawan sudah puas dengan tingkat kepatuhan terhadap } \\
\text { disiplin kerja dengan hadir pada setiap hari kerja. }\end{array}$ \\
\hline 5 & $\begin{array}{l}\text { Usia mempengaruhi } \\
\text { kepuasan kerja }\end{array}$ & 3,15 & $\begin{array}{l}\text { Karyawan sudah cukup puas dengan pekerjaan saat ini karena } \\
\text { usia karyawan mmpengaruhi kepuasan kerja }\end{array}$ \\
\hline 6 & Tingkat usia & 3,37 & $\begin{array}{l}\text { Tingkat usia karyawan berpengaruh pada kepuasan kerja } \\
\text { sehingga pada usia tertentu pencapaian kepuasan kerja akan } \\
\text { berbeda }\end{array}$ \\
\hline 7 & $\begin{array}{l}\text { Puas dengan pekerjaan } \\
\text { saat ini }\end{array}$ & 3,12 & $\begin{array}{l}\text { Karyawan cukup puas dengan pekerjaan saat ini karena sesuai } \\
\text { dengan keahlian yang dimiliki. }\end{array}$ \\
\hline 8 & Tingkat pekerjaan & 3,12 & Karyawan cukup puas dengan pekerjaan yang saat ini dimiliki \\
\hline & Rata-rata & 3,22 & Cukup Puas \\
\hline
\end{tabular}


Dari hasil rekapitulasi pada Tabel 8 diartikan bahwa rata-rata nilai kepuasan kerja karyawan masuk kedalam kategori cukup puas, artinya usaha perusahaan untuk mencapai kepuasan kerja pada karyawan masih dirasa kurang maksimal.

Hasil Uji Faktor-Faktor Promosi Jabatan dan Kompensasi Terhadap Kepuasan Kerja Karyawan pada PT. Perwita Margasakti Jakarta

Berdasarkan perhitungan dengan menggunakan software SPSS for Windows, maka diperoleh:
Kriteria pengambilan keputusan uji $\mathrm{F}$ adalah membandingkan antara Fhitung deengan $\mathrm{F}_{\text {tabel. }}$ Jika $\mathrm{F}_{\text {hitung }}$ lebih besar dari $\mathrm{F}_{\text {tabel }}$ ( $\left.F_{\text {hitung }}>F_{\text {tabel }}\right)$ maka variabel promosi jabatan $\left(\mathrm{X}_{1}\right)$ dan kompensasi $\left(\mathrm{X}_{2}\right)$ berpengaruh terhadap variabel kepuasan kerja (Y). Sebaliknya, bila $F_{\text {hitung }}$ lebih kecil dari $F_{\text {tabel }}$ ( $\left.F_{\text {hitung }}>\mathrm{F}_{\text {tabel }}\right)$ artinya tidak berpengaruh secara simultan.

Dari hasil nilai $F$ pada Tabel 9 tersebut, Fhitung 38.167 dan nilai $\mathrm{F}_{\text {tabel }}$ untuk $\alpha=0,05$ di mana $F_{\text {hitung }}>F_{\text {tabel }}$ pada tingkat kepercayaan $95 \%$ variabel promosi jabatan $\left(\mathrm{X}_{1}\right)$ dan kompensasi $\left(\mathrm{X}_{2}\right)$ mempunyai

Tabel 9 Rangkuman Hasil Perhitungan Faktor-Faktor Promosi Jabatan dan Kompensasi Terhadap Kepuasan Kerja Karyawan

\begin{tabular}{|c|c|c|c|c|c|}
\hline \multirow[t]{2}{*}{ Model } & \multicolumn{2}{|c|}{ Unstandardized Coefficients } & Standardized & $T$ & Sig. \\
\hline & $B$ & Std. Error & Beta & & \\
\hline (Constant) & .901 & 3.064 & & .294 & .770 \\
\hline $\mathrm{X}_{1}$ & .298 & .072 & .491 & 4.159 & .000 \\
\hline$X_{2}$ & .285 & .127 & .265 & 2.244 & .028 \\
\hline t-tabel & $=1.992$ & & & & \\
\hline F-hitung & $=38.167$ & & & & \\
\hline Sig. & $=0.000$ & & & & \\
\hline F-tabel & $=19.483$ & & & & \\
\hline $\mathrm{R}$ & $=0,708$ & & & & \\
\hline $\mathrm{R}^{2}$ & $=0.501$ & & & & \\
\hline Adjusted $\mathrm{R}^{2}$ & $=0.488$ & & & & \\
\hline SEE & $=2.221$ & & & & \\
\hline
\end{tabular}

Sumber : Data Diolah, 2017

Berdasarkan hasil ringkasan pada Tabel 9 diperoleh R Square sebesar 0,501 atau 50,1\%. Artinya bahwa persentase sumbangan pengaruh variabel promosi jabatan $\left(\mathrm{X}_{1}\right)$ dan kompensasi $\left(\mathrm{X}_{2}\right)$ terhadap kepuasan kerja (Y) sebesar $50,1 \%$. Sedangkan sisanya sebesar $49,9 \%$ dipengaruhi oleh variabel lain yang tidak ada dalam penelitian ini.

Sebelum digunakan sebagai dasar kesimpulan, persamaan regresi diperoleh dan telah memenuhi asumsi regresi terlebih dahulu diuji koefesien regresinya. Adapun pengujian bisa dilakukan secara simultan dengan menggunakan uji $\mathrm{F}$ atau secara parsial dengan menggunakan uji t. pengaruh positif dan signifikan terhadap kepuasan kerja (Y) karyawan PT. Perwita Margasakti.

Setelah dilakukan uji F, maka kriteria pengambilan keputusan secara parsial dilakukan dengan menggunaka Uji t. Uji t dilakukan dengan membandingkan thitung dengan $t_{\text {tabel. }}$. Jika $t_{\text {hitung }}$ lebih besar dari $t_{\text {tabel }}$ ( $\left.t_{\text {hitung }}>t_{\text {tabel }}\right)$, artinya bahwa variabel promosi jabatan $\left(\mathrm{X}_{1}\right)$ dan kompensasi $\left(\mathrm{X}_{2}\right)$ berpengaruh secara parsial terhadap variabel kepuasan kerja (Y). Sebaliknya, bila t-hitung lebih kecil dari $t_{\text {tabel }}\left(\mathrm{t}_{\text {hitung }}<\mathrm{t}_{\text {tabel }}\right)$ artinya tidak berpengaruh secara parsial. 
Dari hasil nilai t pada Tabel 9 tersebut, $\mathrm{t}_{1 \text {-hitung }}$ 4,159 dan $\mathrm{t}_{2 \text {-hitung 2,244 serta nilai }}$ $t_{\text {-tabel }} 1,992$ untuk $\alpha=0,05$ di mana $t_{1 \text {-hitung }}>t$ tabel dan $\mathrm{t}_{2 \text {-hitung }}>\mathrm{t}$-tabel pada tingkat kepercayaan $95 \%$ variabel promosi jabatan $\left(\mathrm{X}_{1}\right)$ dan kompensasi $\left(\mathrm{X}_{2}\right)$ secara parsial mempunyai pengaruh positif dan signifikan terhadap kepuasan kerja (Y) karyawan.

\section{KESIMPULAN DAN IMPLIKASI}

Dari hasil dan pembahasan penelitian dapat disimpulkan:

1) Promosi jabatan dan kompensasi secara simultan berpengaruh positif dan signifikan pada kepuasan kerja; 2) Promosi jabatan secara parsial berpengaruh positif dan signifikan terhadap kepuasan kerja; 3) Kompensasi secara parsial berpengaruh positif dan signifikan pada kepuasan kerja.

Adapun saran yang dapat diberikan:

1) Sebaiknya perusahaan meningkatkan peluang promosi jabatan serta memperjelas informasi tentang syarat-syarat pemberian promosi jabatan sehingga kepuasan karja akan bertambah. 2) Sebaiknya perusahaan meningkatkan pemberian kompensasi secara berkala dan sesuai PP No. 78 tahun 2015 sehingga kepuasan kerja bertambah 3) Sebaiknya pihak perusahaan secara berkala menjadwalkan pertemuan untuk setiap karyawan, agar terjalin komunikasi antar karyawan agar terwujud kerjasama lebih baik. Adapun bentuk pertemuan dilakukan berbagai kegiatan seperti rekreasi dan pembuatan group baik dalam dunia nyata maupun sosial media. 4) Sebaiknya pihak perusahaan membuat kebijakan tentang pemberian gaji agar kepuasan kerja meningkat, serta memberikan insentif dengan memperhatikan hal-hal lain agar gaji karyawan meningkat. Adapun beberapa cara bisa dijadikan pertimbangan penilaian prestasi kerja, pencapaian target, serta beban kerja karyawan. 5) Bagi peneliti selanjutnya, khususnya yang tertarik dan berminat meneliti lebih dalam lagi mengenai promosi jabatan dan kompensasi serta kepuasan kerja diharapkan mampu mengembangkan penelitian dengan berusaha membahas secara detil tentang faktor-faktor yang peningkatan kepuasan kerja serta dapat jumlah populasi menambah agar penelitian dapat dilakukan lebih luas sehingga meningkatkan pengaruh lain untuk kepuasan kerja seperti isi pekerjaan, supervisi, organisasi, rekan kerja dan kondisi kerja.

\section{UCAPAN TERIMAKASIH}

Ucapan terima kasih kepada PT. Perwita Margasakti Jakarta

\section{DAFTAR PUSTAKA}

Arikunto, S. 2006. Prosedur Penelitian. Suatu Pendekatan Praktik. Ed Revisi VI. Jakarta. PT. Rineka Cipta.

Hasibuan, Malayu. 2012. Manajemen Sumber Daya Manusia. Jakarta. PT Bumi Aksara.

Mangkunegara., Anwar Prabu AA. 2009. Manajemen Sumber Daya Manusia Perusahaan. Bandung. PT Remaja Rosdakarya.

Nazir, Mohamad. 2003. Metode Penelitian Bisnis. Jakarta. Ghalia Indonesia.

Rivai, Veithzal. 2008. Pervormance Apparsial. Jakarta. PT. Raja Grafindo Persada.

Simamora, Henry. 2005. Manajemen Sumber Daya Manusia. Yogyakarta. STIE YKPN.

Sugiyono. 2009. Metode penelitian Pendidikan Pendekatan kuantitatif, Kualitatif, dan $R \& D$. Bandung. Alfabeta. 